\title{
ANALISIS GAYA BELAJAR SISWA DISLEKSIA
}

\author{
Fitri Siti Sundari ${ }^{\left.a^{*}\right)}$, Cicih Handayani ${ }^{a)}$ \\ ${ }^{a)}$ Universitas Pakuan, Bogor, Indonesia \\ *)e-mail korespondensi : fitri.siti.sundari@unpak.ac.id
}

Riwayat Artikel : diterima: 05 Februari 2020; direvisi: 16 Februari 2020; disetujui: 20 Februari 2020

\begin{abstract}
Abstrak. Penelitian ini menerapkan penelitian studi kasus dengan pendekatan kualitatif. Tujuan dalam penelitian ini adalah untuk mendeskripsikan temuan pada gaya belajar siswa disleksia di Sekolah Dasar Negeri Dago Kabupaten Bogor tahun pelajaran 2018/2019. Subjek penelitian ini adalah salah satu siswa yang berasal dari Sekolah Dasar Negeri Dago Kabupaten Bogor tahun pelajaran 2018/2019. Penelitian ini dilakukan pada semester ganjil tahun pelajaran 2018/2019. Prosedur pengumpulan data dan perekaman data dilaksanakan melalui observasi, wawancara, dan dokumentasi. Teknik analisa data dilakukan dengan tahap reduksi data, penyajian data, dan verifikasi (penarikan kesimpulan). Peneliti menggunakan uji kredibilitas, transferabilitas, dependabilitas, dan konfirmabilitas untuk memperoleh keabsahan data. Hasil penelitian menunjukkan bahwa gaya belajar siswa disleksia di SDN Negeri Dago 02 menunjukkan gaya belajar kinestetik, proses belajar yang membutuhkan banyak gerak atau aktivitas fisik. Berdasarkan hasil penelitian dapat disimpulkan bahwa siswa disleksia memiliki gaya belajar kinestetik, pada saat proses belajar di kelas Rendi lebih mudah memahami atau menangkap pelajaran dengan aktifitas atau kegiatan yang melibatkan bayak gerak atau fisik.
\end{abstract}

Kata Kunci: gaya belajar; disleksia

\begin{abstract}
ANALYSIS OF LEARNING STYLE OF DYSLEXIA
Abstract. This research applies case study research with a qualitative approach. The purpose of this study was to describe the findings on the learning styles of dyslexic students in Dago State Elementary School, Bogor Regency, 2018/2019. The subject of this study was one of the students who came from Dago State Elementary School, Bogor Regency, 2018/2019 academic year. This research was conducted in the odd semester of the 2018/2019 academic year. The procedure for collecting data and recording data is carried out through observation, interviews, and documentation. Data analysis techniques are carried out by the stage of data reduction, data presentation, and verification (conclusion drawing). The researcher uses credibility, transferability, dependability, and confirmability tests to obtain data validity. The results showed that the learning styles of dyslexic students at SDN Negeri Dago 02 showed kinesthetic learning styles, learning processes that required a lot of movement or physical activity. Based on the results of the study it can be concluded that dyslexia students have a kinesthetic learning style, during the learning process in the Rendi class it is easier to understand or capture lessons with activities or activities that involve a lot of motion or physical activity.
\end{abstract}

Keywords: learning style, dyslexia

\section{PENDAHULUAN}

Pendidikan merupakan usaha yang terencana untuk mewujudkan suasana belajar dan proses pembelajaran agar siswa secara aktif mengembangkan potensinya, akan tetapi anak-anak sering mengalami kesulitan belajar. Pada dasarnya kesulitan belajar tidak hanya dialami oleh siswa berkemampuan rendah saja, tetapi juga dialami oleh siswa berkemampuan tinggi. Selain itu, kesulitan belajar juga dapat dialami oleh siswa berkemampuan rata-rata (normal) disebabkan oleh faktor-faktor tertentu yang menghambat tercapainya kinerja akademik sesuai dengan harapan.

Masalah gangguan belajar pada anak-anak sering kali ditemukan. Masalah ini timbul bisa di sekolah maupun di luar sekolah. Anak yang mengalami gangguan belajar biasanya akan mengalami hambatan-hambatan di dalam kegiatan belajarnya seperti pemusatan konsentrasi, gangguan daya ingat, gangguan membaca, gangguan menulis, berhitung, dan lain-lain. Dampak yang dialami oleh anak yang mengalami gangguan belajar bukan hanya pada tumbuh kembangnya, tetapi juga berdampak pada proses interaksi anak dengan dunia sekitarnya, bahkan dengan keluarganya.

Pada proses kegiatan belajar mengajar yang paling terlihat dari siswa yaitu gaya belajar, yang telah diketahui bahwa gaya belajar bisa menjadi salah satu aspek dalam menggapai suatu prestasi akademik. Karena gaya belajar itu dimiliki oleh setiap siswa dan dilakukan setiap hari selama siswa itu melakukan kegiatan belajar. Setiap orang memiliki gaya belajar masing-masing. Bagi guru dengan mengetahui gaya belajar tiap siswa maka guru dapat menerapkan teknik dan strategi yang tepat baik dalam pembelajaran maupun dalam pengembangan diri. Hanya dengan penerapan yang sesuai maka tingkat keberhasilannya lebih tinggi. Seorang siswa juga harus memahami jenis gaya belajarnya. Ia telah memiliki kemampuan mengenal diri yang lebih baik dan mengetahui kebutuhannya. Pengenalan gaya belajar akan memberikan pelayanan yang tepat terhadap apa dan bagaimana sebaiknya disediakan dan dilakukan agar pembelajaran dapat berlangsung optimal .

keberhasilan siswa dalam belajar menyadari hal ini, siswa mampu menyerap dan mengolah informasi dan 
menjadikan belajar lebih mudah dengan gaya belajar siswa sendiri. Penggunaan gaya belajar yang dibatasi hanya dalam satu bentuk, terutama yang bersifat verbal atau dengan jalur auditorial, tentunya dapat menyebabkan adanya ketimpangan dalam menyerap informasi. Oleh karena itu, dalam kegiatan belajar, siswa perlu dibantu dan diarahkan untuk mengenali gaya belajar yang sesuai dengan dirinya sehingga tujuan pembelajaran dapat dicapai secara efektif.

Setiap orang memiliki gaya belajar yang berbedabeda. Sebagian orang mungkin memiliki gaya belajar yang cenderung mendominasi ke salah satu gaya belajar tertentu. Kemampuan seseorang untuk memahami dan menyerap pelajaran sudah pasti berbeda tingkatannya ada yang dapat memahami dengan cepat, sedang dan ada pula yang sangat lambat. Setiap siswa tertentu dan dalam kondisi tertentu mempunyai gaya belajar yang berbeda pada situasi yang berbeda pula, sehingga memungkinkan untuk setiap individu atau siswa mempunyai banyak gaya belajar tergantung pada situasi yang dihadapi. Salah satu contoh adalah siswa disleksia yang berkesulitan belajar didalam situasi tersebut menyebabkan siswa hanya memiliki satu gaya belajar tetapi berbeda halnya dengan siswa normal yang bisa mengikuti pembelajaran dengan baik bisa saja siswa tersebut memiliki lebih dari satu gaya belajar.

Berdasarkan hasil observasi dan wawancara yang dilaksanakan pada tanggal 16 oktober 2018 fakta yang terjadi di sekolah dasar Negeri Dago 02, guru kelas menuturkan bahwa terdapat siswa disleksia di kelas IV hal ini dikarenakan siswa tersebut mengalami kesulitan dalam belajar. Kesulitan dalam membaca dan menulis. Kemampuan berbahasa lisan juga siswa ini mengalami kesulitan misalnya dalam berbicara kurang jelas. Hasil pengamatan kemampuan sehari-hari yang dilakukan wali kelas tersebut terdapat satu siswa yang mengalami kesulitan belajar dikelasnya. Pada saat proses pembelajaran guru menjelaskan materi anak tersebut memperhatikan akan tetapi tidak dapat menerima pembelajaran dengan baik, dan sering berjalan-jalan dikelas, ketika guru meminta untuk membaca kalimat atau paragraf dia sulit untuk membacanya, ada pula kata yang dibaca secara terbalik.

Menurut wali kelas cara penulisan siswa tersebut ada beberapa huruf yang terbalik misalnya huruf $\mathrm{b}$ menjadi $\mathrm{d}$ dan tulisannya kurang rapi, akan tetapi di bidang non akademik dia sangat aktif dan bersemangat pada pembelajaran olahraga, sehingga siswa tersebut lebih menyukai pembelajaran yang berkaitan dengan proses belajar yang membutuhkan banyak gerak. Perilaku dia di sekolah tidak banyak berinteraksi dengan teman sebayanya karena merasa tidak percaya diri. Walaupun banyak kekurangan pada siswa tersebut dia rajin untuk masuk sekolah stiap hari, dan tidak pernah datang terlambat. Sekolah SDN Dago 02 mengadakan kegiatan belajar tambahan bagi siswa yang mengalami kesulitan belajar khususnya terhadap siswa tersebut mendapatkan perhatian khusus dari sekolah.Seringkali disleksia merujuk pada kondisi dimana kesulitan belajar yang nampak pada individu tersebut sulit dijelaskan karena demikian 'berlawanan' dengan potensi kecerdasan yang dimilikinya. Sebagian besar orang awam memahami disleksia sebagai kondisi dimana anak sulit belajar baca, malas menulis. Jika menulis banyak huruf yang hilang, sulit menghitung, dan sebagainya, namun sejatinya disleksia sama sekali tidak sesederhana itu.

Merujuk dari hasil penelitian terdahulu menunjukan bahwa gaya belajar siswa berbeda-beda. Sesuai dengan penelitian yang ditulis oleh Fitriani [1] mengenai gaya belajar siswa kelas III SDN Tukangan Yogyakarta menunjukan terdapat perbedaan gaya belajar siswa bervariasi antara visual, auditori dan kinestetik. Selanjutnya hasil penelitian terdahulu yang ditulis oleh Juliani [2] mengenai gaya belajar siswa dalam pembelajaran bahasa Indonesia pada siswa kelas $\mathrm{V}$ menunjukan bahwa gaya belajar siswa dalam pembelajaran bahasa Indonesia yang dominan dimiliki siswa adalah gaya belajar visual. Kemampuan seseorang untuk memahami, menyerap dan kemudian mengatur serta mengolah informasi. pelajaran sudah pasti berbeda tingkatnya. Proses pembelajaran siswa akan melakukan beberapa cara atau strategi dalam memahami sebuah materi pelajaran dengan gaya belajarnya masing-masing.

Pengertian gaya belajar menurut Susilo [3] gaya belajar sering didefinisikan sebagai cara-cara yang digunakan untuk mempermudah proses belajar. Adapun menurut Ghufron dan Rini [4] menyatakan bahwa gaya belajar merupakan sebuah pendekatan yang menjelaskan mengenai bagaimana individu belajar atau cara yang ditempuh oleh masing-masing orang untuk berkonsentrasi pada proses, dan menguasai informasi yang sulit dan baru melalui persepsi yang berbeda.Gaya belajar didefinisikan sebagai pola individualistis pembelajaran yang membantu peserta didik terhadap pembelajaran, pemecahan masalah, dan pengolahan informasi berlainan satu dengan lainnya Faryadi [5]. Sedangkan menurut pendapat Uno [6] gaya belajar adalah kemampuan seseorang untuk memahami dan menyerap pelajaran dengan cara yang berbeda-beda ada yang cepat, sedang dan ada pula yang sangat lambat.

Dalam proses pembelajaran siswa akan melakukan beberapa cara atau strategi dalam memahami sebuah materi pelajaran dengan gaya belajarnya masing-masing, gaya belajar itu diterapkan berdasarkan kemampuan menyerap informasi yang dimiliki siswa. Pengertian gaya belajar menurut pendapat Suparman [7] menjelaskan bahwa gaya belajar adalah kombinasi dari bagaimana seseorang menyerap, kemampuan mengatur dan mengolah informasi. Adapun menurut Priyatna [8] gaya belajar adalah cara di mana anak-anak menerima informasi baru dan proses yang akan mereka gunakan untuk belajar.

Dalam rangka pengembangan potensi diri, setiap siswa mempunyai kemampuan yang berbeda-beda. Ada siswa yang dapat mencapainya tanpa kesulitan,namun tidak sedikit siswa mengalami banyak kesulitan. Hal tersebut sebagaimana dikemukakan menurut Rofiah [9] disleksia adalah salah satu jenis kesulitan belajar pada anak ketidakmampuan membaca. Adapun menurut Fyanda [10] disleksia adalah anak yang memiliki gangguan belajar dalam hal membaca yang mungkin bisa terjadi karena bawaan lahir (keturunan) atau faktor yang disebabkan dari luar. 
Sedangkan menurut pendapat Thompson [11] disleksia merupakan salah satu disabilitas. Tidaklah mengejutkan jika hal itu dianggap sebagai sesuatu yang kontrovesial, karena secara alami, cara seseorang memperoleh kemampuan aksara sangatlah kompleks.

Disleksia merupakan sebuah kondisi ketidak mampuan belajar pada seseorang yang disebabkan oleh kesulitan dalam melakukan aktivitas membaca dan menulis. Gangguan ini bukan bentuk dari ketidakmampuan fisik, seperti masalah gangguan penglihatan, tetapi mengarah pada otak yang telah mengolah dan memproses informasi yang sedang dibaca. Hal tersebut dikemukan oleh Lidwina [12] Sedangkan menurut Widyorini dan Julia [13] disleksia adalah suatu gangguan yang ekslusif, ia tidak disebabkan oleh suatu masalah atau suatu gangguan dan adanya disleksia tidak akan menyebabkan gangguan lainnya.

Berdasarkan teori yang telah dibahas maka peneliti dapat mensintesiskan bahwa gaya belajar siswa disleksia adalah cara siswa menerima atau merespon suatu pembelajaran dengan kemampuan yang dimilikinya melalui gerakan atau aktifitas fisik.

\section{METODE PENELITIAN}

Jenis penelitian ini menggunakan pendekatan penelitian kualitatif bertujuan untuk mengungkapkan data yang ada dilapangan dengan cara menguraikan dan menginterpretasikan sesuatu seperti apa yang ada di lapangan, dan menghubungkan sebab akibat terhadap sesuatu yang terjadi pada saat penelitian, dengan tujuan untuk memperoleh gambaran nyata dan mendalam mengenai gaya belajar siswa disleksia. di Sekolah Dasar Negeri Dago 02 Kabupaten Bogor yang dilaksanakan pada tanggal 08 Juni sampai 20 Juni 2019. Subjek dalam penelitian ini adalah seorang siswi kelas IV yang memiliki kesulitan belajar yaitu membaca dan menulis..

Metode penelitian yang digunakan dalam penelitian adalah metode studi kasus. Metode studi kasus yaitu dengan cara mengumpulkan data melalui observasi dan wawancara lalu menganalisis data yang diperoleh dari hasil observasi, wawancara dan dokumentasi. Penggunaan metode studi kasus ini diharapkan peneliti dapat menemukan masalah dan menyajikan secara langsung.

Siklus prosedur pengumpulan data terdiri dari studi pendahuluan, tahapan perencanaan, fokus penelitian, pengumpulan data dengan menggunakan metode triangulasi, analisis data, pengumpulan data, pengecekan keabsahan data, dan penarikan kesimpulan. Studi ini lebih menitik beratkan pada pengkajian proses dan fenomena pendidikan yang saling terkait. Studi ini lebih menitikberatkan pada pengkajian fenomena dan proses pendidikan yang terkait. Sumber informasi adalah yang dapat memberikan informasi yang kaya bagi kedalam studi.

Beberapa responden yang akan terlibat yaitu orang tua, guru kelas serta siswa dislekisa itu sendiri karena mereka yang dianggap mampu memberikan informasi yang relevan dan terpercaya. Peneliti pun akan mengikuti dan mengamati keseharian subjek. Sekolah dan tempat tinggal subjek akan dijadikan lokasi penelitian sehingga peneliti bisa mendapatkan informasi lebih banyak lagi melalui lokasi tersebut.

Teknik pengumpulan data pada penelitian ini menggunakan teknik triangulasi yakni gabungan antara observasi (pengamatan), interview (wawancara), dan dokumentasi. Teknik triangulasi yaitu dengan menggabungkan beberapa teknik dalam pengumpulan data menurut Sugiono [14]. Hasil pengumpulan data dilapangan akan tertulis dalam catatan lapangan.

Analisis data dalam penelitian kualitatif dilakukan dengan prosedur dan teknis pengolahan berikut: melakukan pemilahan dan penyusunan klasifikasi data, melakukan penyunting data dan pemberian kode data untuk membangun kinerja analisis data, melakukan konfirmasi data yang memerlukan verifikasi data dan pendalaman data, melakukan analisis data sesuai dengan konstruksi pembahasan hasil penelitian.

\section{HASIL DAN PEMBAHASAN}

Data dari hasil peneliti yang telah dilakukan dari tanggal 08 Mei sampai dengan 20 Mei 2019 di sekolah dan di rumah subjek. Data penelitian ini dilakukan secara interaktif dan berlangsung secara terus menerus sampai tuntas, sampai data yang peneliti dapatkan menemukan titik jenuh. Data ini peneliti peroleh dari hasil observasi, wawancara dan dokumentasi mengenai gaya belajar siswa disleksia.

Pada penelitian ini, peneliti melibatkan narasumber sebagai informan yang sangat penting untuk menggali informasi tentang gaya belajar siswa disleksia. Narasumber yang dimaksud yaitu subjek yang diteliti di sekolah, guru kelas dan orang tua yang memberikan tambahan informasi terhadap aktivitas belajar anaknya ketika di kelas dan di rumah untuk peneliti mendapatkan informasi yang akurat.

Informasi yang peneliti peroleh dari subjek dan narasumber yang meliputi subjek, guru kelas dan orang tua, peneliti telah mencatat dalam suatu format catatan penelitian sesuai dengan aturan penelitian. Yakni hasil observasi, pengamatan, wawancara dan dokumentasi dicatat dalam catatan lapangan.

Berdasarkan hasil observasi dan wawancara Siswa data hasil penelitian mengenai gaya belajar siswa disleksia yang didapat bahwa ketika subjek belajar memiliki gaya belajar yang berbeda dengan yang lain. Subjek yang bernama Rendi memiliki gaya belajar kinestetik. Hal ini ketika subjek melakukan kegiatan belajar di kelas, pada saat guru menjelaskan materi terihat subjek tidak bisa diam dalam waktu yang lama banyak melakukan gerakan-gerakan fisik, sering menyentuh temannya untuk mendapatkan perhatiannya, dan selalu jalan-jalan di kelas untuk menyentuh temannya. Pada saat pembelajaran Bahasa Indonesia guru meminta siswa nya untuk membaca, ketika subjek membaca terlihat kesulitan dan tidak lancar, artikulasi atau pengucapanya tidak jelas dan sering menggunakan jarinya untuk menunjuk serta menggerakkan bibirnya ketika membaca, meskipun subjek merasa kesulitan dalam 
membaca subjek selalu berusaha untuk membacanya dengan bersemangat, akan tetapi subjek siswa yang aktif dan bersemangat terhadap aktifitas yang menggunakan banyak gerak atau fisik dan tidak kesulitan untuk melakukan aktifitas seperti siswa normal. Subjek senang olahraga dan sering ikut latihan bermain petanque bersama teman lainnya. Pada saat menulis subjek juga terlihat kesulitan dan lambat dalam menulis sehingga sering tertinggal oleh temantemannya dan tulisan subjek pun tidak rapi banyak huruf yang tidak ditulis dengan tepat. Ketika di rumah dan di sekolah subjek senang dengan permainan tradisional seperti engrang, bermain kucing-kucingan bersama temannya. Subjek melakukan aktifitas sehari-hari seperti anak seusianya yang tidak mengalami kesulitaan dalam belajar, membaca dan menullis. Berdasarkan wawancara dan dokumentasi yang dilakukan guru Ibu Wahyuni S.Pd Pada saat pembelajaran dimulai guru mengecek kehadiran terlebih dahulu, guru mengkondisikan siswanya, sebelum menjelaskan materi guru selalu memberikan apresiasi dan dilanjutkan dengan membahas materi menggunakan metode ceramah akan tetapi guru kadang menggunakan metode lainnya dari hasil pengamatan peneliti ketika guru megajar sedikit memperhatikan siswa yang memiliki kesulitan belajar membaca dan menulis atau disebut dengan disleksia. Namun tidak ada ada perbedaan dalam meyampaikan materi guru fokus kesemua siswanya. Ketika guru meminta subjek untuk membaca dengan sabar membantunya dan selalu membimbing ketika ada siswa yang merasa kesulitan dalam belajar tidak hanya siswa disleksia saja yang dibimbing, kemudian guru memberikan evaluasi setelah itu guru membahas kembali materi yang sudah dipelajari.

Hasil wawancara dengan guru yang peneliti dapatkan, guru mengungkapkan bahwa subjek memiliki perbedaan dengan teman lainnya ketika belajar subjek sering berisik dan tidak bisa diam dalam waktu lama, subjek membacanya tidak lancar dan kadang tidak bisa membedakan huruf yang mirip seperti b dan d, subjek membaca sering terbalik dan susah mengambil point atau kesimpulan dari materi, tulisan subjek tidak rapi dan tidak terbaca karena banyak kata yang tidak ditulis. Guru mengatakan bahwa subjek lebih senang berolahraga daripada belajar di kelas.

Berdasarkan data hasil wawancara dengan orang tua subjek bernama Ibu Mimin yang sudah peneliti dapatkan bahwa orang tua subjek mengatakan subjek ketika berbicara tidak jelas dan sering kesulitan dalam membaca dan menulis. Ketika di rumah subjek lebih senang bermain bersama teman-temannya sampai lupa kalau ada tugas dari sekolah atau PR, subjek senang bermain engrang dan kucing-kucing ketika sedang di rumah, subjek tidak bisa diam dalam waktu lama lebih sering keluar rumah untuk bermain. Subjek juga sering mengganggu saudaranya untuk mendapatkan perhatiannya, subjek dari penampilan selalu asal asalan dimana hal yang sama seperti mengerjakan sesuatu sering asal-asalan, tulisan subjek pun tidak rapi dan tidak terbaca, subjek sering teriak-teriak dengan nada yang tinggi ketika memanggil orang lain maupn ibunya

Hasil wawancara, observasi, dan penelusuran dokumen mengenai Gaya Belajar Siswa Disleksia.
Menunjukan fakta-fakta empirik sebagai berikut : Subjek senang menyentuh orang lain untuk mendapatkan perhatiannya, Subjek ketika belajar selalu berjalan-jalan didalam kelas, Subjek sangat menyukai olahraga, Subjek menggunakan jari untuk menunjuk saat membaca, Subjek menggerakkan bibir/ melafalkan kata saat membaca, Subjek tidak bisa duduk dalam waktu yang lama, Subjek memiliki tulisan tangan yang tidak rapi, dan Subjek senang bermain permainan tradisional.

Permasalahan yang diungkap dalam penelitian ini untuk memperoleh gambaran gaya belajar siswa disleksia di Sekolah Dasar Negeri Dago 02 Kabupaten Bogor. Dalam masalah gaya belajar siswa disleksia peneliti harus mengetahui dan memahaminya dengan kesulitan belajar membaca dan menulis yang siswa alami.

Berdasarkan temuan penelitian subjek mengenai gaya belajar siswa disleksia di Sekolah Dasar Negeri Dago 02 adalah bahwa gaya belajar kinestetik yang cendrung mengandalkan belajar dengan banyak gerakan. Penelitian ini sudah diteliti pada siswa kelas IV di Sekolah Dasar Negeri Dago 02 kaabupaten bogor dari tanggal 08 Mei 2019 sampai 20 Mei 2019. Pada saat proses belajar di kelas Rendi lebih mudah memahami atau menangkap pelajaran dengan aktifitas atau kegiatan yang melibatkan bayak gerak atau fisik.

Selama peneliti melakukan penelitian gaya belajar siswa disleksia tersebut, terlihat bahwa subjek disleksia menunjukan gaya belajar kinestetik. Gaya belajar belajar kinestetik adalah belajar melalui bergerak, menyentuh dan melakukan aktifitas fisik. Siswa yang seperti ini sulit untuk duduk diam berjam-jam karena keinginan mereka untuk beraktifitas dan eksplorasi sangatlah kuat Sutikno [15]. Gaya belajar kinestetik adalah gaya belajar dengan memanfaatkan kelebihan berupa tenaga atau pergerakan. Anak dengan gaya belajar kinestetik lebih menyukai aktivitas bergerak dan interaksi dalam kelompoknya. Biasanya, mereka agak sulit disuruh diam dalam waktu yang lama. Mereka akan selalu bergerak aktif dan bereksplorasi dengan kondisi sekitar. Bahkan, ketika dipaksa duduk dalam jangka waktu lama, yang muncul adalah kejenuhan (Sri [16]).

Karakteristik gaya belajar kinestetik dikemukakan oleh Uno [6] bahwa Ada beberapa karakteristik model belajar seperti ini yang tak semua orang bisa melakukannya. a) menempatkan tangan sebagai alat penerima informasi utama agar kita bisa terus mengingatnya, b) hanya dengan memegang kita bisa menyerap informasinya tanpa harus membaca penjelasannya, c) kita termasuk orang yang tidak bisa/tahan duduk terlalu lama untuk mendengarkan pelajaran, d) kita merasa bisa belajar lebih baik apabila disertai dengan kegiatan fisik, dan karakter terakhir e) orang yang memilik gaya belajar ini memiliki kemampuan mengkoordinasikan sebuah tim dan kemampuan mengendalikan gerak tubuh (athletic ability).

Pada saat proses pembelajaran Rendi memang lebih mengandalkan fisik atau lebih banyak gerak. Rendi mengalami kesullitan membaca dan menulis serta berbicaranya tidak lancar sehingga subjek merasa kesulitan ketika proses belajar, dimana proses belajar diawali dengan 
kemampuan membaca sebagai jendela ilmu pengetahuan, dan kualitas tulisannya tidak rapi, sulit untuk memberikan spasi pada setiap kata dalam satu kalimat dan sulit dimengerti. Walapun subjek mengalami kekurangan dalam belajar tetapi subjek tetap bersemangat untuk sekolah dan selalu aktif dalam pembelajaran olahraga. Anak yang mengalami kesulitan membaca, menulis dan lambat dalam berbicara disebut disleksia. Lidwina [12] disleksia merupakan sebuah kondisi ketidakmampuan belajar pada seseorang yang disebabkan oleh kesulitan dalam melakukan aktivitas membaca dan menulis. Gangguan ini bukan bentuk dari ketidakmampuan fisik, seperti masalah gangguan penglihatan, tetapi mengarah pada otak yang telah mengolah dan memproses informasi yang sedang dibaca. Sedangkan menurut Rofiah [9] disleksia adalah salah satu jenis kesulitan belajar pada anak ketidakmampuan membaca. Disleksia menurut Widyorini dan Julia [13] disleksia adalah suatu gangguan yang ekslusif, ia tidak disebabkan oleh suatu masalah atau suatu gangguan dan adanya disleksia tidak akan menyebabkan gangguan lainnya.

Semangat dan motivasi sangat diperlukan dalam belajar seorang anak. Rendi memiliki semangat untuk belajar dan harus ada dorongan dari orang-orang terdekatnya. Peran orang tua dan guru sangat diperlukan untuk memahami, membantu, membimbing, mengarahkan dan mengajarkan kepada anak untuk belajar dengan baik dan semangat. Anak akan menjadi lebih baik dan bersemangat apabila anak tersebut dibimbing dan dididik sebaik mungkin oleh orang terdekatnya terutama orang tua. Memberi kesempatan pada anak yang mengalami kesulitan belajar yaitu membaca dan menulis atau disebut dengan disleksia untuk belajar sesuai dengan karakteristiknya, memberi bimbingan individu dan bimbingan kelompok, serta memeberikan motivasi kepada anak.

Dengan demikian penelitian yang ditulis oleh Bunga Fitria Fyanda [10], Soeisniwati Lidwina [12], Desti Pratiwi [13], dan Kusumawati [17] Persamaan penelitian ini dari penelitian di atas yaitu pada penelitian pertama dan kedua terdapat kesamaan disleksia dan kesamaan penelitian ketiga,empat dan lima terdapat kesamaan gaya belajar berprestasi.

\section{SIMPULAN}

Berdasarkan pembahasan hasil penelitian dan temuan data mengenai gaya belajar siswa disleksia yang telah diuraikan sebelumnya, maka dapat diambil simpulan bahwa Gaya belajar siswa disleksia menunjukan gaya belajar kinestetik. Gaya belajar yang cenderung mengandalkan gerak atau aktivitas fisik, pada saat subjek belajar selalu berjalan-jalan di kelas, tidak bisa duduk dalam waktu yang lama selalu banyak gerakan yang dilakukan, senang menyentuh orang untuk mendapatkan perhatiannya, memiki tulisan yang tidak rapi, menggunakan jari untuk menunjuk pada saat membaca, ketika membaca sering menggerakkan bibirnya dan subjek sangat menyukai olahraga serta permainan tradisional karena banyak melibatkan gerakan dan aktivitas fisik. Ketika di rumah pun subjek sama senang bermain dengan teman-temannya yang banyak melibatkan gerakan atau aktivitas fisik. Walaupun subjek memiliki kekurangan dalam belajar seperti menulis dan membaca berbeda dari teman-temannya subjek selalu berusaha untuk mengikuti pembelajaran di sekolah serta subjek sangat rajin untuk masuk sekolah karena orangtua subjek selalu mendukungnya.

\section{REFERENSI}

[1] Fitriani, Cris Hilda. 2017. Gaya Belajar Siswa Kelas III B SDN Tukangan Yogyakarta. PGSD : Universitas Negeri Yogyakarta. Diakses 8 Juli 2019.

[2] Juliani 2016. Analisis Gaya Belajar Siswa Dalam Pembelajaran Bahasa Indonesia Pada Siswa KelasV SD Gugus VI. PGSD : Universitas Pendidikan Ganesa. Diakses 8 Juli 2019.

[3] Susilo, M Joko. 2009. Sukses dengan Gaya Belajar. Yogyakarta : Pinus.

[4] Ghufron, M Nur dan Rini Risnawita, S. 2014. Gaya Belajar Kajian Teoritik. Yogyakarta:Pustaka Pelajar.

[5] Faryadi, Qais. 2017. Pedoman Mengajar Efektif. Bandung : PT Remaja.

[6] Uno, Hamzah B. 2012. Orientasi Baru dalam Psikologi Pembelajaran. Jakarta : PT Bumi Askara

[7] Suparman S. 2010. Gaya Mengajar yang Menyenangkan Siswa. Yogyakarta : PinusBook Publisher.

[8] Priyatna, Andri. 2013. Pahami Gaya Belajar Anak : Memaksimalkan Potensi Anak dengan Modifikasi Gaya Belajar. : PT Elex Media Komputindo

[9] Rofiah, Nurul Hidayati. 2015. Proses Identifikasi : "Mengenal Anak Kesulitan Belajar Tipe Disleksia Bagi Guru Sekolah Dasar Inklusi”. PGSD FKIP UAD. Vol. 2 : 116.

[10] Fyanda, Bunga Fitria. 2011. Upaya Guru Mengatasi Kesulitan Belajar Anak Disleksia di SD Negeri 10 Banda Aceh. FKIP Unsyiah. Vol 3(3), hal 53-61. Di akses 28 oktober 2018 .

[11] Thompson, Jenny. 2012. Memahami Anak Berkebutuhan Khusus. Esensi : Erlangga

[12] Lidwina, Soeisniwati. 2012. Disleksia Berpengaruh Pada Kemampuan Membaca dan Menulis. JURNAL STIE SEMARANG. Vol. 4,(3),hal. 9-18.

[13] Pratiwi, Desti dkk. 2014. Gaya Belajar Dominan Pada Siswa Berprestasi Dalam Kegiatan Pembelajaran di SD Negeri 2 Gombong Tahun ajaran 2013/2014. FKIP PGSD Universitas Sebelas Maret tahun. Vol Diakses 3 Februari 2019.

[13] Widyorini, Endang dan Julia Maria Van Tiel. 2017. Disleksia : Deteksi. Diagnosis, Penanganan di Sekolah dan di Rumah. Jakarta : Prenada.

[14] Sugiyono. 2009. Metode Penelitian Kuantitatif, Kualitatif, R\&D , Bandung: Alfbeth. CV

[15] Sutikno, Sobri. 2013. Belajar Dan Pembelajaran "Upaya Kreatif dalam Mewujudkan Pembelajaran yang Berhasil". Lombok : Holistica

[16] Sri, christina P. 2017. Bukan Supermom tapi Smartmom. Yogyakarta:Laksana. 
[17] Kusumawati dkk. 2018. Gaya Belajar Siswa Berpretasi Pada Mata Pelajaran Matematika Kelas V SD Negeri 03 Cibelok Pemalang. FKIP PGSD Universitas PGRI Semarang. Vol. 6,(2), hal 1-10. 